\title{
Testing of a commercial waterpipe electric heater and a research-grade waterpipe electric heater
}

\author{
Ronald L. Edwards', Rashele Moore', Rudaina Alrefai-Kirkpatrick', Sarah A. Amyot ${ }^{1}$
}

\begin{abstract}
INTRODUCTION The capability of a commercial waterpipe electric heater to simulate the waterpipe charcoal heating system using waterpipe tobacco consumption as a metric was evaluated, and a research-grade waterpipe electric heater to standardize waterpipe tobacco emission testing was designed.

METHODS The experiment was conducted in two phases. In Phase 1, tobacco was heated using either charcoal or a commercial electric heater. The tobacco temperature was recorded during a 57-minute machine-smoking session and tobacco consumption was measured. In Phase 2 , a similar procedure was followed using a novel research-grade electric heater.

RESULTS In Phase 1, tobacco consumption using either charcoal or the commercial electric heater averaged $31.35 \%$ and $20.56 \%$, respectively. In Phase 2 , tobacco consumption using the research-grade electric heater, set at target temperatures of $470,430,400,380,370$ and $350^{\circ} \mathrm{C}$, averaged $55.74,41.22,40.18,39.10,31.57$ and $26.14 \%$, respectively.

CONCLUSIONS The commercial electric heater did not reach consumption levels seen in the charcoal heating system, whereas the research-grade electric heater did and can be used as part of a standardize waterpipe tobacco emission testing regimen.
\end{abstract}

\section{AFFILIATION \\ 1 Office of Science, Center for Tobacco Products, United States Food and Drug Administration, Calverton, United States \\ CORRESPONDENCE TO \\ Ronald L. Edwards. Office of Science, Center for Tobacco Products, United States Food and Drug Administration, Beltsville Drive, 11785, Calverton, MD 20705, United States. E-mail: ronald. edwards@fda.hhs.gov}

\section{KEYWORDS}

charcoal, hookah, tobacco regulation, waterpipe tobacco, narghile shisha

Received: 18 May 2020

Revised: 1 July 2020

Accepted: 13 July 2020

\section{INTRODUCTION}

The United States Food and Drug Administration (FDA) was granted authority in June 2009 by the Family Smoking Prevention and Tobacco Control Act to regulate the manufacture, distribution, and marketing of tobacco products under Chapter IX of the Food, Drug, and Cosmetic Act (FD\&C Act). To reduce the death and disease from tobacco products, FDA finalized a rule (deeming rule) in May 2016 extending its authority over any additional current and future tobacco products, including components and parts but excluding accessories of the newly deemed products ${ }^{1}$. Products that meet the statutory definition of 'tobacco products' include currently marketed products such as dissolvables not already regulated by FDA, waterpipe tobacco, electronic nicotine delivery systems (ENDS, including e-cigarettes, e-hookah, e-cigars, vape pens, advanced refillable personal vaporizers, and electronic pipes), cigars, and pipe tobacco. Under the rule, the deemed tobacco products are subject to the same FD\&C Act provisions and relevant regulatory requirements as cigarettes, cigarette tobacco, rollyour-own tobacco, and smokeless tobacco, including the requirement of premarket review and the submission of ingredient listing, and reporting of harmful and potentially harmful chemicals (HPHCs). Subject to these requirements are waterpipe tobacco components including flavor enhancers and the vials in which they are contained, hose cooling attachments, water filtration base additives (including those which are flavored), waterpipe tobacco charcoals and the wrappers or boxes that contain the charcoals, and bowls, valves, hoses and heads.

It is documented that waterpipe smoking has 
increased among youth in the United States ${ }^{2}$. The increase in waterpipe use is mostly due to its marketing strategies promoting flavored waterpipe tobacco smoking as a palatable alternative to cigarettes, lack of previous regulation, social acceptance, and a perceived reduction in harm compared to cigarettes ${ }^{3}$. A waterpipe, also known as hookah, narghile shisha, arguile, arghile, hubblebubble, or goza, consists of a bowl that is partially filled with waterpipe tobacco and heated with burning waterpipe charcoal placed on top to produce smoke that passes through water prior to inhalation by the user. Various studies have found that the associated health risks of waterpipe smoking include exposure to potential carcinogens such as polycyclic aromatic hydrocarbons ${ }^{4}$, nicotine addiction ${ }^{4}$, cardiovascular disease ${ }^{5}$, chronic obstructive pulmonary disease ${ }^{6}$, and lung cancer ${ }^{7}$. The HPHCs in waterpipe tobacco are similar to cigarette tobacco with the primary HPHCs in waterpipe emissions consisting of carbon monoxide, nicotine, particulate matter, volatile organic chemicals, acrolein, arsenic, and heavy metals ${ }^{3}$.

To evaluate the health impacts of waterpipe smoking, it is important to evaluate the heating methods used during waterpipe smoking. Waterpipe heating components can potentially emit different HPHCs depending on the heating methods used. For example, a study performed by Monzer et al. ${ }^{8}$ using an electrical heating element found that $90 \%$ of the carbon monoxide and $75-92 \%$ of the $4-$ and 5-membered ring polyaromatic hydrocarbon compounds in the waterpipe mainstream smoke came from the charcoal ${ }^{8}$. An evaluation of the thermal performance in waterpipe tobacco smoking using waterpipe charcoal and three separate commercial waterpipe electric heaters showed variation in waterpipe tobacco consumption across the four heating units ${ }^{9}$. By understanding waterpipe tobacco temperature and consumption during different waterpipe heating methods, researchers can potentially provide more reproducible consumption levels in standardized testing depending on the heating method used. Therefore, the establishment and conduct of heating test methods is an important area of research for public health. In addition, heating test methods, that use waterpipe charcoal to heat the waterpipe tobacco, mix both the burning charcoal and heated tobacco emissions once smoke is formed and drawn into the waterpipe. This can potentially create a challenge for standardized testing methods in determining the source of the compounds in the waterpipe wastewater or smoke. A possible solution to the mixed emission conundrum could be to standardize a commercial waterpipe electric heater or construct a research-grade waterpipe electric heater in order to reach temperature and consumption levels seen in a waterpipe charcoal heating system and remove its emissions.

The goal of this study is to inform standardizing waterpipe tobacco heating by removing waterpipe charcoal. Therefore, a commercial waterpipe electric heater was tested, and accordingly, a research-grade waterpipe electric heater was designed and tested, to provide more reproducible consumption levels in waterpipe tobacco.

\section{METHODS}

\section{Phase 1}

In the first phase of the experiment, the use of a commercial waterpipe electric heater (Ren, Headstream, China, 40-mm diameter) (Figure 1) was compared with the use of a quick-light waterpipe

\section{Figure 1. Commercial waterpipe electric heater (СЕH) size}

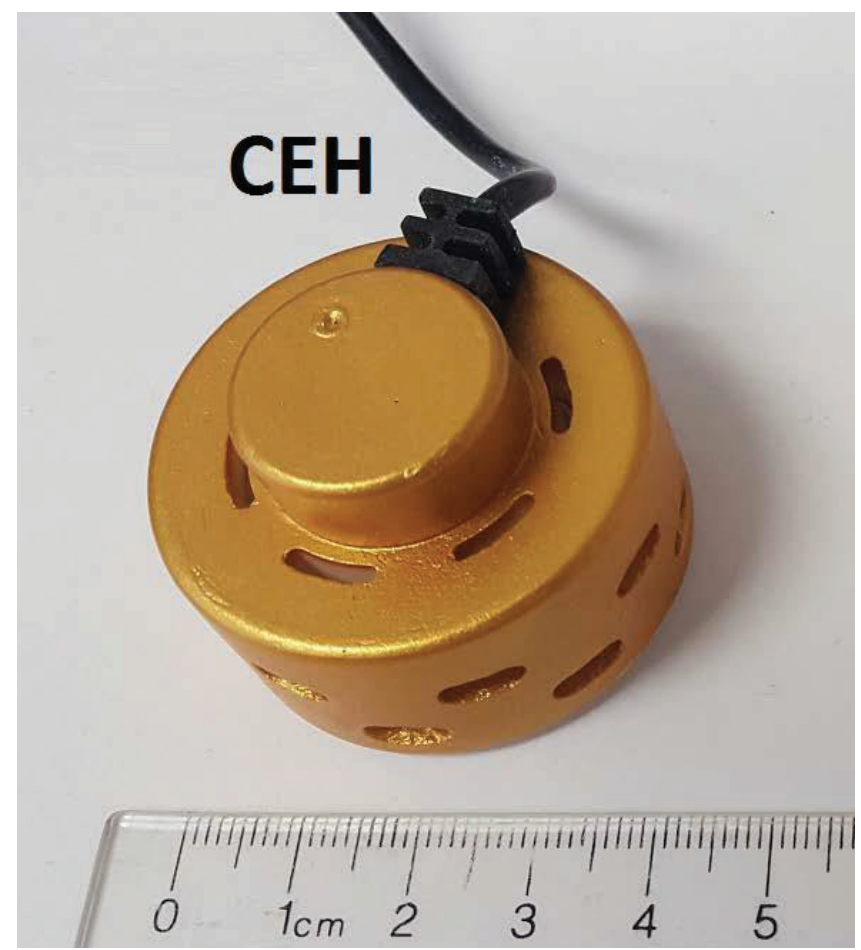


charcoal (Three Kings Holland, $40 \mathrm{~mm}$ diameter) heating system to heat the tobacco in the waterpipe smoking sessions. The commercial waterpipe electric heater was powered by the manufacturer's power supply (stated as $13 \mathrm{~V} \mathrm{DC}$ and 3.5 A current). However, based on internal measurements, the voltage measured $14 \mathrm{~V}$ DC with $2.7 \Omega$ resistance, resulting in approximately a $5.2 \mathrm{~A}$ current.

Waterpipe charcoal or the commercial waterpipe electric heater was placed on the top of the researchgrade waterpipe ${ }^{10}$ Pyrex head containing $10 \mathrm{~g}$ of waterpipe tobacco (Two Apples, Nakhla), which was wrapped in perforated aluminum foil $(9 \times 9$ $\mathrm{cm}, 18$ holes). The modified Beirut Method was applied using the following protocol: 171 puffs, 2.6 $\mathrm{s}$ puff duration, $0.53 \mathrm{~L}$ puff volume, $17 \mathrm{~s}$ inter-puff interval, and 57-min smoking session. A calibrated smoking machine (Hawktech FP2000 with waterpipe manifold) to simulate waterpipe smoking was used to perform the puffing protocol. For the waterpipe charcoal smoking sessions, we preheated an initial piece of waterpipe charcoal (approximately 10 g) and then placed it on top of the foil. At puff 99, an additional half piece of waterpipe charcoal (approximately $5 \mathrm{~g}$ ) was preheated and then placed on the foil at puff 105 .

To obtain temperature readings of the waterpipe tobacco during heating while using waterpipe charcoal or the commercial waterpipe electric heater, thermocouples were placed within the tobacco at approximately 10, 15 and $20 \mathrm{~mm}$ from the top of the research-grade waterpipe head. In addition, thermocouple temperature readings were measured from underneath the waterpipe charcoal and commercial waterpipe electric heater. During the 57-minute smoking session, the temperature was recorded every 60 seconds with the Yokogawa MW100 scalable, high-performance data-acquisition/data-logging platform. A total of three smoking sessions were conducted per heating source. Waterpipe tobacco consumption was calculated for each smoking session using a per cent change calculation in weight of the waterpipe tobacco prior to and after heating with waterpipe charcoal or the commercial waterpipe electric heater.

\section{Phase 2}

In the second phase of the experiment, a research- grade waterpipe electric heater was designed, constructed, and tested, that met the following three design parameter criteria to simulate the waterpipe charcoal heating system used with a research-grade waterpipe:

1. The research-grade waterpipe electric heater size and shape were similar to that of popularly used waterpipe charcoal (approximately $40 \mathrm{~mm}$ in diameter by $30 \mathrm{~mm}$ in height) and was lightweight (approximately $100 \mathrm{~g}$ ) in order to allow placement on top of the aluminum foil that covers the waterpipe head.

2. The research-grade waterpipe electric heater was capable of reaching the heating profile of the waterpipe charcoal (up to $500^{\circ} \mathrm{C}$ in approximately 15 minutes) and able to accurately control its temperature to within a target value $\left( \pm 5^{\circ} \mathrm{C}\right)$ not to exceed $570^{\circ} \mathrm{C}$.

3. The research-grade waterpipe electric heater was composed of chemically resistant, inert, nonabsorptive materials that can withstand high temperatures without degrading.

Based on these design requirements, an anodized aluminum was chosen as the research-grade waterpipe electric heater material. To obtain the desired size, heating, and chemical resistance parameters, it was estimated that a $100 \mathrm{~g}$ aluminum cylinder could be heated to $500^{\circ} \mathrm{C}$ at $100 \mathrm{~W}$ within about 2 minutes. The research-grade waterpipe electric heater had a center diameter of $34 \mathrm{~mm}$ and a center height of $20 \mathrm{~mm}$, with top and bottom flanges of $5 \mathrm{~mm}$ height each, totaling an overall diameter and height of 42 and $30 \mathrm{~mm}$, respectively (Figure 2).

Two $2 \mathrm{~mm}$ diameter holes were drilled into the top of the research-grade waterpipe electric heater so the thermocouples could be inserted. One thermocouple was used for the Yokogawa MW100, which had been used in Phase 1 for data acquisition of the waterpipe charcoal and commercial waterpipe electric heater. The other thermocouple was attached to the Lake Shore 336 Temperature Controller for feedback temperature control. Approximately 120 $\mathrm{cm}$ of nichrome wire with a diameter of $0.25 \mathrm{~mm}$ and a resistance of about $0.21 \Omega$ per $\mathrm{cm}$ was wrapped around the anodized aluminum cylinder to provide a total electrical heating resistance of about $25 \Omega$. A Resbound 920 Electrically Resistant and Thermally Conductive Adhesive (Cotronics, Brooklyn, NY) was 
Figure 2. Constructed research-grade waterpipe electric heater size (REH), and REH schematic diagram*
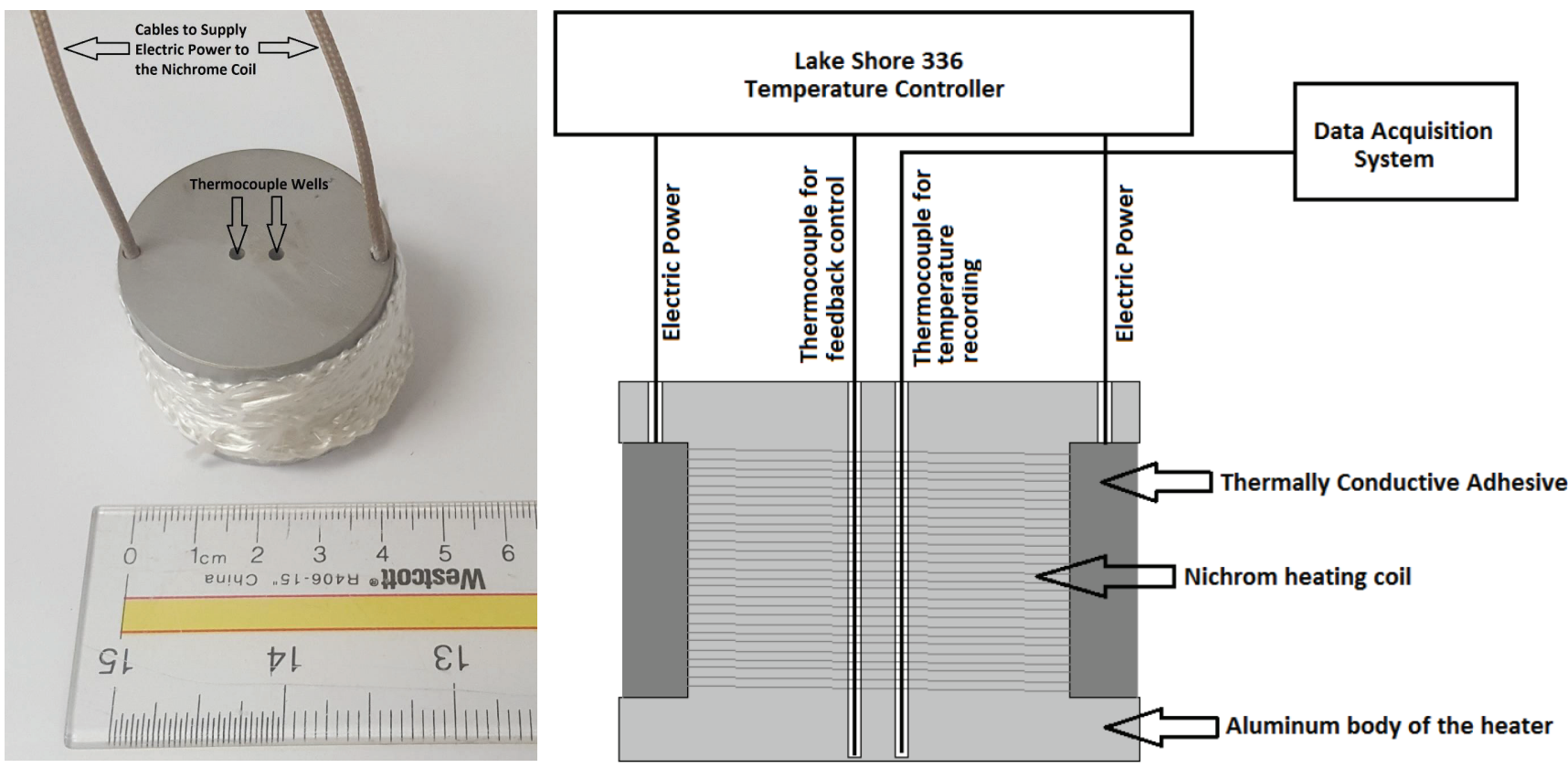

${ }^{*}$ Figure not drawn to any scale.

utilized to keep the nichrome wire in place while also providing electrical isolation between wire wraps. Isolation between the aluminum cylinder and the wire wraps was provided by the anodized layer (Figure 2). A Lake Shore High Precision Temperature Controller Model 336 was utilized to control the heating temperature. The Lake Shore Model 336 was able to control the temperature up to about $800^{\circ} \mathrm{C}$, which provided a total power of $150 \mathrm{~W}$.

The Phase 2 part of this study used the same modified Beirut Method as Phase 1, with the waterpipe tobacco setup of the research-grade waterpipe to assess whether the research-grade waterpipe electric heater could reach the heating profile of the waterpipe charcoal from Phase 1 . As in Phase 1, we placed thermocouples in the waterpipe tobacco at approximately 10, 15 and 20 $\mathrm{mm}$ from the top of the research-grade waterpipe head and at various locations within the tobacco in the head to measure waterpipe tobacco temperature. Temperature readings were also measured by thermocouples placed underneath the researchgrade waterpipe electric heater. Every minute during the three replicated 57-minute smoking sessions, temperatures were monitored and recorded using the Yokogawa MW100 for data acquisition and waterpipe tobacco consumption was then calculated.

\section{RESULTS}

\section{Phase 1}

A comparison was made with the waterpipe charcoal and commercial waterpipe electric heater heating characteristics using data collected from the three test runs on heating temperatures, waterpipe tobacco temperatures and calculated waterpipe tobacco consumptions (Table 1). The waterpipe charcoal temperature increased slowly and reached its maximum temperature after approximately 15 minutes. The average waterpipe charcoal temperature of the three smoking sessions ranged from $405^{\circ} \mathrm{C}$ to $450.6^{\circ} \mathrm{C}$, and averaged $429.7^{\circ} \mathrm{C}(\mathrm{SD}=23.05)$, with the maximum waterpipe charcoal temperature ranging from $523.8^{\circ} \mathrm{C}$ to $531.2^{\circ} \mathrm{C}$, and averaging $526.4^{\circ} \mathrm{C}(\mathrm{SD}=4.19)$. The average waterpipe tobacco temperature over the three smoking sessions ranged from $116.5^{\circ} \mathrm{C}$ to $122.4^{\circ} \mathrm{C}$, and averaged $118.5^{\circ} \mathrm{C}$ $(\mathrm{SD}=3.38)$. The amount of waterpipe tobacco consumed using the waterpipe charcoal heating source over three smoking sessions ranged from $28.41 \%$ to $33.23 \%$, and averaged $31.35 \%(\mathrm{SD}=2.58)$.

The commercial waterpipe electric heater temperature quickly reached maximum temperature 
Table 1. Temperature and consumption results following 57 minutes of heating with waterpipe charcoal, a commercial waterpipe electric heater, and a research-grade waterpipe electric heater

\begin{tabular}{|c|c|c|c|c|c|c|}
\hline Heating supply & $\begin{array}{l}\text { Test } \\
\text { runs }\end{array}$ & $\begin{array}{c}\text { Set } \\
T\left({ }^{\circ} \mathrm{C}\right)\end{array}$ & $\begin{array}{l}\text { Average T-output of } \\
\text { heating supply }\left({ }^{\circ} \mathrm{C}\right) \\
\text { (mean; SD) }\end{array}$ & $\begin{array}{l}\text { Maximum } \\
\text { T-output of heating } \\
\text { supply }\left({ }^{\circ} \mathrm{C}\right) \\
\text { (mean; SD) }\end{array}$ & Tobacco $\mathrm{T}\left({ }^{\circ} \mathrm{C}\right)$ & $\begin{array}{c}\text { Tobacco consumption } \\
\text { percentage (\%) } \\
\text { (mean; SD) }\end{array}$ \\
\hline Waterpipe charcoal & 3 & - & $\begin{array}{l}433.6,450.6,405.0 \\
\quad(429.7 ; 23.05)\end{array}$ & $\begin{array}{l}523.8,531.2,524.1 \\
\quad(526.4 ; 4.19)\end{array}$ & $\begin{array}{l}122.4,116.6,116.5 \\
\quad(118.5 ; 3.38)\end{array}$ & $\begin{array}{c}32.40,33.23,28.41 \\
(31.35 ; 2.58)\end{array}$ \\
\hline $\begin{array}{l}\text { Commercial waterpipe } \\
\text { electric heater }\end{array}$ & 3 & - & $\begin{array}{l}401.6,378.3,379.1 \\
\quad(386.3 ; 13.23)\end{array}$ & $\begin{array}{l}432.9,404.1,398.6 \\
\quad(411.9 ; 18.42)\end{array}$ & $\begin{array}{l}109.1,102.2,100.3 \\
\quad(103.9 ; 4.63)\end{array}$ & $\begin{array}{c}22.02,19.42,20.24 \\
(20.56 ; 1.33)\end{array}$ \\
\hline \multirow[t]{6}{*}{$\begin{array}{l}\text { Research-grade waterpipe } \\
\text { electric heater }\end{array}$} & 3 & 350 & $\begin{array}{c}341.9,345.9,347.7 \\
(345.2 ; 2.97)\end{array}$ & $\begin{array}{c}352.4,354.1,354.9 \\
(353.8 ; 1.28)\end{array}$ & $\begin{array}{l}117.2,118.6,119.1 \\
\quad(118.3 ; 0.98)\end{array}$ & $\begin{array}{c}26.92,25.07,26.44 \\
(26.14 ; 0.96)\end{array}$ \\
\hline & 1 & 370 & 361.9 & 375.0 & 129.5 & 31.57 \\
\hline & 1 & 380 & 375.1 & 383.9 & 126.7 & 39.10 \\
\hline & 1 & 400 & 393.2 & 404.3 & 139.8 & 40.18 \\
\hline & 1 & 430 & 406.1 & 435.8 & 140.8 & 41.22 \\
\hline & 3 & 470 & $\begin{array}{c}450.8,448.0,450.8 \\
(449.8 ; 1.61)\end{array}$ & $\begin{array}{c}474.9,473.6,475.5 \\
(474.7 ; 0.97)\end{array}$ & $\begin{array}{c}150.4,148.9,140.8 \\
(147.4 ; 5.16)\end{array}$ & $\begin{array}{c}57.01,61.94,48.26 \\
(55.74 ; 6.93)\end{array}$ \\
\hline
\end{tabular}

T: temperature. SD: standard deviation.

within 2 minutes of heating time; after reaching maximum temperature, the temperature plateaued and then oscillated between $350^{\circ} \mathrm{C}$ and $450^{\circ} \mathrm{C}$. The average commercial waterpipe electric heater output temperature over the three smoking sessions ranged from $378.3^{\circ} \mathrm{C}$ to $401.6^{\circ} \mathrm{C}$, and averaged $386.3^{\circ} \mathrm{C}$ $(\mathrm{SD}=13.23)$, with the maximum temperature ranging from $398.6^{\circ} \mathrm{C}$ to $432.9^{\circ} \mathrm{C}$, and averaging $411.9^{\circ} \mathrm{C}(\mathrm{SD}=18.42)$. The average waterpipe tobacco temperature over the three smoking sessions ranged from $100.3^{\circ} \mathrm{C}$ to $109.1^{\circ} \mathrm{C}$ with an average of $103.9^{\circ} \mathrm{C}$ $(\mathrm{SD}=4.63)$. The amount of waterpipe tobacco consumed using the commercial waterpipe electric heater over three smoking sessions ranged from $19.42 \%$ to $22.02 \%$, and averaged $20.56 \%(\mathrm{SD}=1.33)$.

\section{Phase 2}

The research-grade waterpipe electric heater was constructed and subjected to the waterpipe charcoal smoking regimen from Phase 1 (Table 1). The average temperature of the three smoking sessions of waterpipe tobacco heated by the research-grade waterpipe electric heater set at $470^{\circ} \mathrm{C}$ target temperature was $147.4^{\circ} \mathrm{C}$, which exceeded the temperature of the waterpipe tobacco heated by the waterpipe charcoal (Figure 3). The overall average waterpipe tobacco temperature during waterpipe charcoal heating ranged from $116.5^{\circ} \mathrm{C}$ to $122.4^{\circ} \mathrm{C}(\mathrm{SD}=3.38)$ and averaged $118.5^{\circ} \mathrm{C}$, compared to $140.8^{\circ} \mathrm{C}$ to $150.4^{\circ} \mathrm{C}$ $(\mathrm{SD}=5.16)$ and an average of $147.4^{\circ} \mathrm{C}$ for waterpipe tobacco heated with the research-grade waterpipe electric heater set at $470^{\circ} \mathrm{C}$. The maximum waterpipe tobacco temperature average (collected during the last 20 minutes of machine smoking) for the waterpipe charcoal ranged from $145.3^{\circ} \mathrm{C}$ to $171.6^{\circ} \mathrm{C}$, compared to $193.4^{\circ} \mathrm{C}$ to $200.5^{\circ} \mathrm{C}$ for waterpipe tobacco heated with the research-grade waterpipe electric heater set at $470^{\circ} \mathrm{C}$ (Figure 3 ). The amount of waterpipe tobacco consumed during the three research-grade waterpipe electric heater smoking sessions set at $470^{\circ} \mathrm{C}$ ranged from $48.26 \%$ to $61.94 \%(\mathrm{SD}=6.93)$ and averaged $55.74 \%$, whereas tobacco consumption from Phase 1 ranged from $28.41 \%$ to $33.23 \%(\mathrm{SD}=2.58)$ and averaged $31.35 \%$ for the three waterpipe charcoal smoking sessions (Figure 4).

Because the research-grade waterpipe electric heater transfers heat to the waterpipe tobacco more efficiently than the waterpipe charcoal, single tests were performed at lower target temperatures for the heater. These target temperatures were set at $370,380,400$ and $430^{\circ} \mathrm{C}$, with average output temperatures of $345.2,361.9,375.1,393.2$ and $406.1^{\circ} \mathrm{C}$, respectively. The target temperatures produced average waterpipe tobacco temperatures 
Figure 3. Waterpipe tobacco temperature results following 57 minutes of heating with waterpipe charcoal, a commercial waterpipe electric heater, and a research-grade waterpipe electric heater

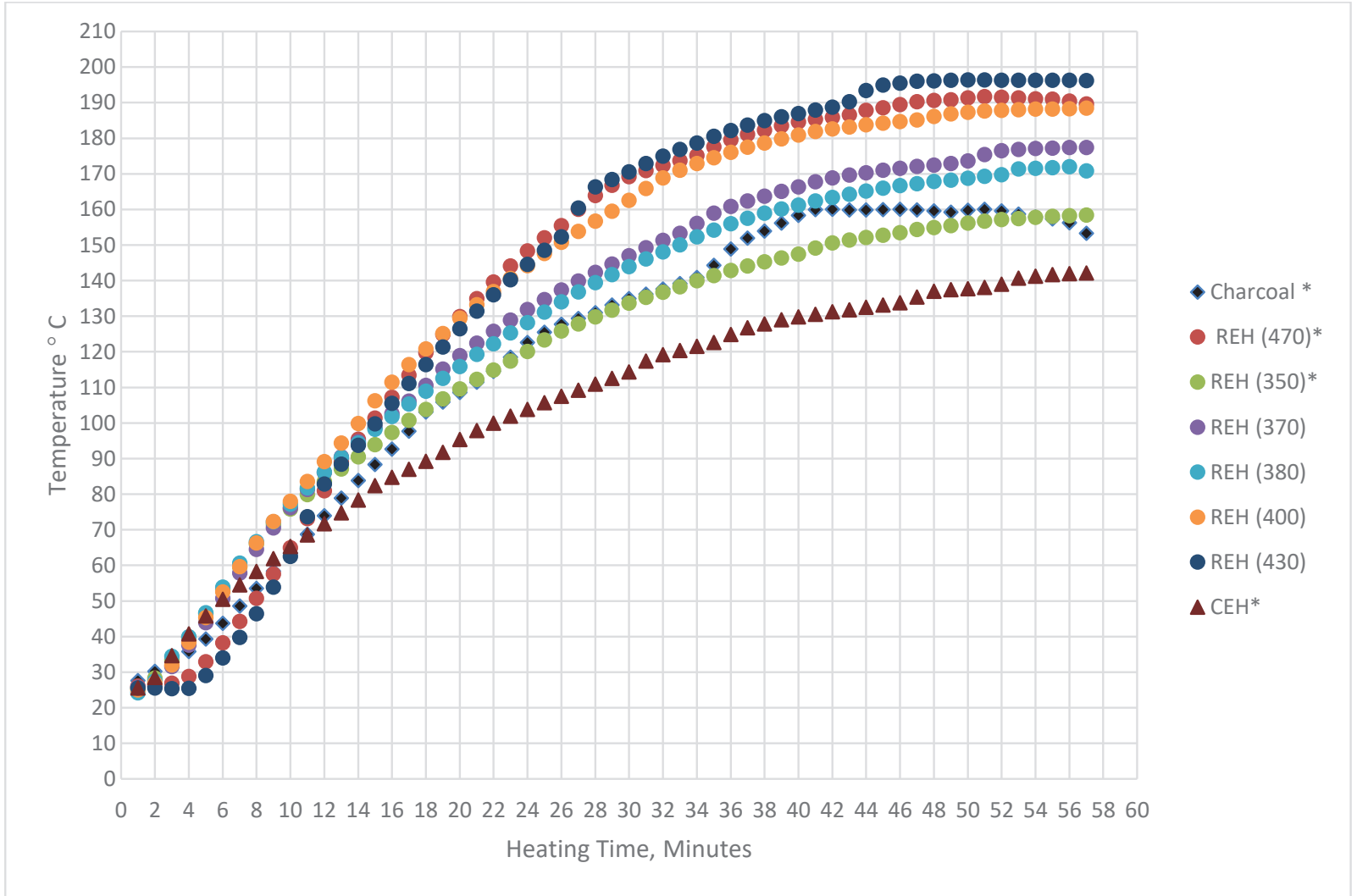

*Average of three waterpipe smoking sessions.

Figure 4. Waterpipe tobacco consumption results following 57 minutes of heating with waterpipe charcoal, a commercial waterpipe electric heater, and a research-grade waterpipe electric heater

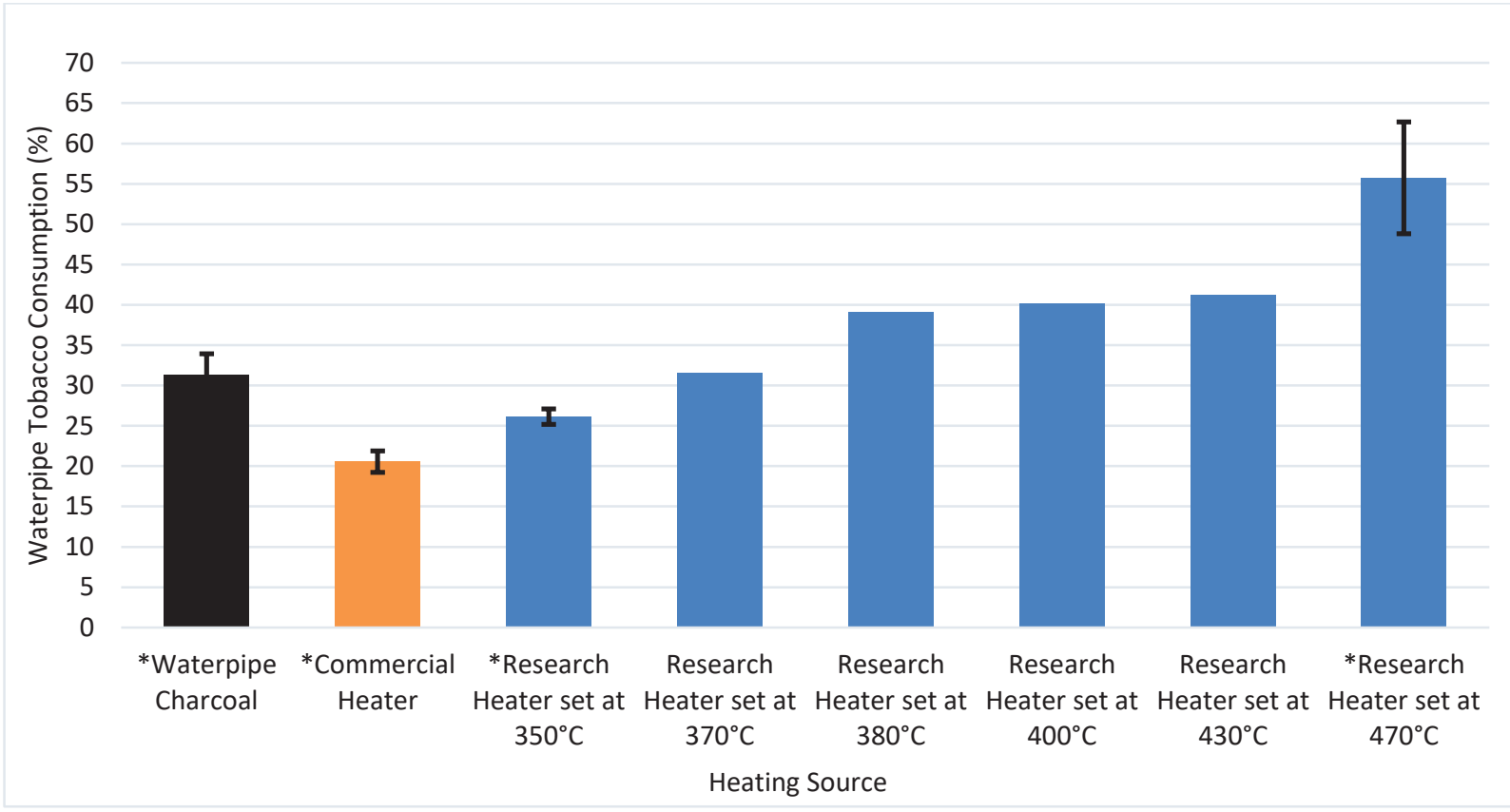

*Average of three waterpipe smoking sessions. 
of $129.5,126.7,139.8$ and $140.8^{\circ} \mathrm{C}$ with waterpipe tobacco consumptions of $31.57,39.10,40.18$ and $41.22 \%$, respectively (Figures 3 and 4 ). Because the majority of the set targets exceeded the waterpipe tobacco consumption acceptance criterion, with $370^{\circ} \mathrm{C}$ resulting in a waterpipe tobacco consumption level closest to that of the waterpipe charcoal system, the research-grade waterpipe electric heater was set to a target temperature of $350^{\circ} \mathrm{C}$ and three replicate test runs were conducted. The amount of waterpipe tobacco consumed during the three research-grade waterpipe electric heater smoking sessions with the heater target temperature set at $350^{\circ} \mathrm{C}$ ranged from $25.07 \%$ to $26.92 \%$ ( $\mathrm{SD}=0.96$ ), with an average of $26.04 \%$ (Figure 4 ).

\section{DISCUSSION}

\section{Phase 1}

The waterpipe tobacco temperatures across the commercial waterpipe electric heater smoking sessions showed greater temperature variability than waterpipe tobacco temperatures for the waterpipe charcoal heating source smoking sessions. A comparison of the commercial waterpipe electric heater and waterpipe charcoal heating temperatures, as well as the waterpipe tobacco temperatures and the calculated consumptions (Table 1 and Figures 3 and 4), revealed that the commercial waterpipe electric heater's heating ability did not reach the temperature and consumption levels of the waterpipe charcoal heating system for the waterpipe tobacco. The average maximum temperature achieved by the commercial waterpipe electric heater was approximately $20 \%$ lower than that of the waterpipe charcoal $\left(411.9^{\circ} \mathrm{C}\right.$ vs $\left.526.4^{\circ} \mathrm{C}\right)$. The inability of the commercial waterpipe electric heater to reach higher average temperatures was verified by the waterpipe tobacco temperatures and consumption levels, which indicated that the waterpipe charcoal heating source can reach higher temperatures with an approximate average consumption of $10 \%$ more waterpipe tobacco. The commercial waterpipe electric heater was not capable of reaching waterpipe charcoal temperatures and tobacco consumption levels. Because the commercial waterpipe electric heater was not able to reach waterpipe charcoal temperature conditions, as seen in the charcoal heating process, a more powerful and stable electrical heating source needed to be developed. This indicated that a research-grade waterpipe electric heater was necessary to reach the waterpipe charcoal heating systems' waterpipe tobacco temperature and consumption levels in order to standardize waterpipe tobacco testing. As a result, we designed and constructed a research-grade waterpipe electric heater and tested its ability to produce a more powerful electric heating source that could reach the heating parameters of waterpipe charcoal.

\section{Phase 2}

A research-grade waterpipe electric heater was constructed and used to compare with waterpipe charcoal smoking testing. The temperature of the waterpipe tobacco heated by the research-grade waterpipe electric heater set at a $470^{\circ} \mathrm{C}$ target temperature exceeded the temperature of the tobacco heated by the waterpipe charcoal (Figure $3)$. Measurements of the research-grade waterpipe electric heater tobacco consumption rate taken over the range of target temperatures from $350^{\circ} \mathrm{C}$ to $470^{\circ} \mathrm{C}$ showed that, to match more closely to charcoal tobacco consumption rates, the research-grade waterpipe electric heater target temperature should be set at about $360^{\circ} \mathrm{C}$ to $370^{\circ} \mathrm{C}$ (Figures 3 and 4 ).

The research-grade waterpipe electric heater has less heat dissipation, and, therefore, it provides higher waterpipe tobacco heating efficiency and percentage of heat energy that is transferred to the tobacco. Less dissipation is due to the researchgrade waterpipe electric heater construction where cylinder walls were wrapped by a thermo-insulating tape, whereas burning waterpipe charcoal had air exchange from all sides except for the bottom. This higher heating efficiency in the researchgrade waterpipe electric heater allowed for lower temperature output compared to the waterpipe charcoal heating system in order to achieve similar waterpipe tobacco consumption levels.

\section{CONCLUSIONS}

The commercial waterpipe electric heater did not reach temperature and consumption levels seen in the charcoal heating system, whereas the researchgrade electric heater did. The use of a research-grade waterpipe electric heater in standardized waterpipe tobacco smoking testing would enable researchers to regulate tobacco temperature in order to reach consumption levels in waterpipe tobacco seen from 
burnt waterpipe charcoal heating. The researchgrade waterpipe electric heater has shown that it can provide reproducible consumption levels comparable to a charcoal heating system. A reliable heating system is important for public health to potentially provide consumption levels similar to a waterpipe charcoal heating system. The ability to provide consistent consumption in waterpipe tobacco heating would be integral in providing important information relevant to the public health of waterpipe users and individuals exposed to waterpipe secondhand and thirdhand smoke.

\section{REFERENCES}

1. Food and Drug Administration. Deeming tobacco products to be subject to the Federal Food, Drug, and Cosmetic act, as amended by the Family Smoking Prevention and Tobacco Control Act; restrictions on the sale and distribution of tobacco products and required warning statements for tobacco products. Fed Regist. 2016;81:28973-29106. PMID:27192730.

2. Gentzke AS, Wang B, Robinson JN, Phillips E, King BA. Curiosity about and susceptibility toward hookah smoking among middle and high school students. Prev Chronic Dis. 2019;16:E04. doi:10.5888/pcd16.180288

3. Badran M, Laher I. Waterpipe (shisha, hookah) smoking, oxidative stress and hidden disease potential. Redox Biology. 2020;34:101455. doi:10.1016/j.redox.2020.101455

4. Sepetdjian E, Shihadeh A, Saliba NA. Measurement of 16 polycyclic aromatic hydrocarbons in narghile waterpipe tobacco smoke. Food Chem Toxicol. 2008;46(5):15821590. doi:10.1016/j.fct.2007.12.028

5. Benowitz NL. Cardiovascular effects of hookah smoking: potential implications for cardiovascular risk. Nicotine Tob Res. 2018;21(9):1151-1161. doi:10.1093/ntr/nty065

6. Bahtouee M, Maleki N, Nekouee F. The prevalence of chronic obstructive pulmonary disease in hookah smokers. Chron Respir Dis. 2018;15(2):165-172. doi:10.1177/1479972317709652

7. Cobb C, Ward KD, Maziak W, Shihadeh AL, Eissenberg T. Waterpipe tobacco smoking: an emerging health crisis in the United States. Am J Health Behav. 2010;34(3):275285. doi:10.5993/ajhb.34.3.3

8. Monzer B, Sepetdjian E, Saliba N and Shihadeh A. Charcoal emissions as a source of CO and carcinogenic $\mathrm{PAH}$ in mainstream narghile waterpipe smoke. Food Chem Toxicol. 2008;46(9):2991-2995. doi:10.1016/j.fct.2008.05.031

9. Hourani ME, Talih S, Salman R, et al. Comparison of $\mathrm{CO}, \mathrm{PAH}$, nicotine, and aldehyde emissions in waterpipe tobacco smoke generated using electrical and charcoal heating methods. Chem Res Toxicol. 2019;32(6):12351240. doi:10.1021/acs.chemrestox.9b00045
10. Brinkman MC, Kim H, Gordon SM, et al. Design and validation of a research-grade waterpipe equipped with puff topography analyzer. Nicotine Tob Res. 2015;18(5):785-793. doi:10.1093/ntr/ntv180
ACKNOWLEDGEMENTS

This work was performed by Battelle Memorial Institute in Columbus, OH, from 15 September 2016 to 20 July 2018. The authors thank Battelle Memorial Institute, Kimberly Benson, Luis Valerio Jr., Hoshing Chang, Megan Mekoli, Deborah Neveleff, Brody Edwards and Marielle C. Brinkman for their contributions to this research.

\section{CONFLICTS OF INTEREST}

The authors have completed and submitted the ICMJE Form for Disclosure of Potential Conflicts of Interest and none was reported.

FUNDING

This research was funded by FDA Contract HHSF223201610607A. The findings and conclusions in this report are those of the authors and do not necessarily represent the official position of the Food and Drug Administration.

\section{PROVENANCE AND PEER REVIEW}

Not commissioned; externally peer reviewed. 